\title{
HUBUNGAN PENGETAHUAN MULTIGRAVIDA TRIMESTER III TENTANG \\ TANDA - TANDA BAHAYA KEHAMILAN \\ DENGAN PEMERIKSAAN KEHAMILAN DI BPM NY. ERWIN \\ ( Desa Titik Kecamatan Kandat Kabupaten Kediri )
}

Siti Komariyah

Akademi Kebidanan Dharma Husada Kediri

\begin{abstract}
ABSTRAK
Selama kehamilan dan perkembangan kehamilan dari bulan ke bulan diperlukan kemampuan seorang ibu hamil untuk beradaptasi dengan perubahanperubahan yang terjadi pada fisik dan mentalnya. Semakin bertambah usia kehamilan, akan mengakibatkan bentuk tubuh ibu berubah yang semula langsing menjadi tidak langsing lagi. Hal itu tidak perlu dikhawatirkan karena perubahan tersebut adalah suatu keadaan yang normal. Penelitian ini bertujuan untuk mengetahui tingkat kecemasan primigravida dalam menghadapi perubahan fisiologi selama kehamilan.

Desain yang digunakan dalam penelitian ini adalah deskriptif. Populasi dalam penelitian ini adalah semua primigravida di BPS Ny. Anik. Sampel dalam penelitian ini sebanyak 22 responden dan diambil secara Total Sampling. Data dikumpulkan dengan menggunakan kuesioner yang berskala HARS dan dianalisa dengan menggunakan editing, coding, scoring, tabulating.

Hasil penelitian terhadap 22 responden didapatkan yang tidak ada kecemasan sebanyak 0 responden $(0 \%)$, kecemasan ringan sebanyak 22 responden $(100 \%)$, kecemasan sedang sebanyak 0 responden $(0 \%)$, dan kecemasan berat sebanyak 0 responden $(0 \%)$.

Kesimpulan dari penelitian ini adalah semua responden mengalami kecemasan ringan yaitu 22 responden (100\%). Oleh karena itu hendaknya bidan bisa memberikan informasi yang dibutuhkan responden khususnya primigravida sehingga responden tidak akan mengalami kecemasan dalam menghadapi kehamilannya.
\end{abstract}

Kata Kunci : Kecemasan, Perubahan Fisiologi Kehamilan 


\section{PENDAHULUAN}

Masa kehamilan hendaknya merupakan masa bahagia menanti kedatangan anak yang diinginkan namun disisi lain ada dua persoalan yang sering dijumpai dalam bidang ilmu jiwa pada wanita yang hamil yaitu; perasaan takut dan penolakan ibu terhadap kehamilan. Perasaan takut ini timbul karena kehamilan menyebabkan

perubahan besar pada badan ibu yang kurang dimengerti hingga dianggap misterius dan kegelisahan misalnya; perut membesar, terasanya pergerakanpergerakan dalam perut, timbulnya hiperpigmentasi, striae, colostrums. Disamping itu calon ibu sering mendengar cerita - cerita yang bukanbukan mengenai bahaya kehamilan dari orang-orang sekitarnya. (Fakultas Kedokteran UNPAD, 2003).

Sampai akhir 2007 jumlah ibu hamil mencapai 4.620.400 orang atau sekitar $3 \%$ dari jumlah penduduk Indonesia. Berbagai upaya telah dilaksanakan untuk menurunkan AKI,

termasuk diantaranya program safe motherhood yang telah dilaksanakan di Indonesia sejak tahun 1988. Akses terhadap pelayanan antenatal sebagai pilar kedua safe motherhood juga cukup baik yaitu 87\% pada tahun 1997 namun mutunya perlu ditingkatkan terus. (Iklanmarker, 2011)

Diperkirakan ada 14 juta kasus perdarahan dalam kehamilan setiap tahunnya dan paling sedikit 128.000 wanita mengalami perdarahan sampai meninggal. Sebagian besar kematian tersebut terjadi dalam waktu 4 jam setelah melahirkan. Di Inggris (2000), separuh kematian ibu hamil akibat disebabkan oleh perdarahan postpartum. Berdasarkan Survei Demografi Kesehatan Indonesia (SDKI) AKI di Indonesia mengalami penurunan yang cukup tinggi, dari 390 pada tahun 2000, angka ini masih termasuk yang tinggi diantara negaranegara ASEAN. Tingginya AKI ini menunjukkan bahwa derajat kesehatan di Indonesia masih belum baik. Pada tahun 2002/2003, AKI di Indonesia adalah sebesar 307 per 100.000 kelahiran hidup. Tingginya AKI dipengaruhi oleh penyebab langsung dan penyebab tidak langsung. Penyebab langsung berkaitan dengan kondisi saat melahirkan seperti perdarahan, hipertensi atau tekanan darah tinggi saat kehamilan (eklamsia), Infeksi, partus lama, dan komplikasi keguguran. Rencana Pembangunan Jangka Menengah Nasional (RPJM) 2004-2009 menerapkan sasaran pencapaian AKI sebesar 226 per 100.000 kelahiran hidup pada tahun 2009. Sementara itu Millenium Development Goals (MDGs), menetapkan AKI pada tahun 2015 menjadi $2 / 3$ dari keadaan tahun 2000 , yaitu menjadi 102 per kelahiran hidup.

Perdarahan Postpartum adalah perdarahan lebih dari 500-600 ml dalam masa 2 jam setelah anak lahir. (Ridwanamiruddin, 2007)

Pada masa ini, ada ibu yang merasa enggan bepergian, bahkan ada yang sampai menarik diri dari aktivitas kehidupan social sebagai seorang ibu. (Mandriwati, 2008:3)

Pada kenyataannya tidak semua ibu primigravida mengalami hal-hal negatif seperti rasa tidak percaya diri dan enggan berpergian. Apabila ibu hamil memandang bahwa kehamilannya adalah suatu keadaan yang membebani kehidupannya maka ia akan sulit 
beradaptasi terhadap perubahan fisik maupun psikisnya. Hal ini sering terjadi pada ibu hamil yang kehamilannya tidak direncanakan, akibat dari kegagalan dalam menggunakan alat kontrasepsi, kehamilan diluar pernikahan, dan kehamilan akibat perkosaan. (Mandriwati, 2008:4)

Menurut (PPDGJ-II, Rev. 1983) diperkirakan jumlah mereka yang menderita gangguan kecemasan baik akut maupun kronik mencapai $5 \%$ dari jumlah penduduk, dengan perbandingan wanita dan pria 2 banding 1 , diperkirakan $2 \%-4 \%$ diantara penduduk dalam kehidupannya mengalami gangguan cemas. (Repository, 2010). Dalam hasil penelitian Susiaty selain usia kehamilan penyebab kecemasan dapat dihubungkan dengan usia ibu yang memberi dapak terhadap perasaan takut dan cemas yaitu dibawah usia 20 ta 28 serta diatas 31-40 tahun karena usia .... merupakan usia kategori kehamilan beresiko tinggi dan seorang ibu yang berusia lebih lanjut akan menanggung resiko yang semakin tinggi untuk melahirkan bayi cacat dengan sindrom down (Susiaty, 2008). Diantara sebanyak 357 wanita hamil, yang dilibatkan dalam penelitian yang dilakukan Lee dan rekan-rekannya,

para ilmuan tersebut menemukan lebih dari separuh (54\%) calon ibu memiliki rasa cemas dan lebih dari sepertiga (37\%) menunjukkan tanda-tanda depresi pada periode tertentu dalam masa kehamilan (Agus, 2008).

Ketakutan terhadap kehamilan dan persalinan adalah reaksi yang fisiologis, kebanyakan orang gelisah menghadapi persalinan. Hal tersebut dapat menimbulkan usaha kearah abortus provokatus yang mungkin membahayakan jiwa ibu, dapat juga terjadi hiperemesis dan persalinan dapat dirasakan sebagai penderitaan, juga dapat mempengaruhi hubungan antara ibu dan anak setelah persalinan. (Fakultas Kedokteran UNPAD, 2003).

Untuk mengatasi perasaan takut ada perlunya ibu diberi penerangan mengenai fisiologi kehamilan, persalinan dan nifas, supaya dapat mengerti perubahan-perubahan yang terjadi dalam dirinya. (Fakultas Kedokteran UNPAD, 2003). Bidan dalam memberikan asuhan harus berstandar kode etik kebidanan agar klien merasa puas dan mengerti atas asuhan yang diberikan. Upaya dalam memberikan asuhan tersebut bidan hendaknya tidak memandang antara kaya dan miskin karena asuhan tersebut sangat bermanfaat bagi siapa saja yang mengalami kesulitan dalam hal kebidanan.

Dari studi pendahuluan didapatkan jumlah ibu hamil primigravida di BPS Ny. Anik sebanyak 10 orang. Dari 10 orang tersebut ternyata ada 6 orang $(60 \%)$ yang tidak tahu tentang perubahan kehamilan dan hanya 4 orang $(40 \%)$ yang tahu tentang perubahan kehamilan. Dari 6 orang tersebut yang merasa cemas ada 4 orang, sedangkan yang tidak merasa cemas ada 2 orang. Cemas atau kecemasan adalah respons terhadap suatu ancaman yang sumbernya tidak diketahui, internal, samar-samar, atau bersifat konflik.

\section{METODE}

Jenis penelitian yang digunakan dalam penelitian ini adalah penelitian deskriptif bentuk rancangan Cross Sectional. Variabel dalam penelitian ini 
adalah variable tunggal, karena desain yang digunakan adalah deskriptif. Variable penelitian ini adalah tingkat kecemasan ibu hamil primigravida dalam menghadapi perubahan fisiologi selama kehamilan. Populasi dalam penelitian ini adalah ibu primigravida di BPS Ny. Anik Desa. Jekek Kecamatan Baron. Kabupaten Nganjuk sejumlah 22 orang. Sampling yang digunakan dalam penelitian ini adalah total sampling Instrument adalah alat ukur penelitian, instrument yang digunakan dalam penelitian ini adalah kuesioner. Analisa data teknik deskriptif

HASIL

Tabel IV.8 Distribusi Frekuensi Tingkat Kecemasan Primigravida Dalam Menghadapi Perubahan Fisiologi Selama Kehamilan di BPS Ny. Anik

\begin{tabular}{clcc} 
No & Tingkat Kecemasan & Frekuensi & Prosentase \\
\hline 1 & Tidak ada kecemasan & 0 & 0 \\
\hline 2 & Kecemasan ringan & 22 & 100 \\
\hline 3 & Kecemasan sedang & 0 & 0 \\
\hline 4 & Kecemasan berat & 0 & 0 \\
\hline & Jumlah & 22 & 100
\end{tabular}

\section{Diskusi}

Berdasarkan hasil penelitian dari 22 responden tentang tingkat kecemasan primigravida dalam menghadapi perubahan fisiologi selama kehamilan pada tabel IV.8 dapat dijelaskan bahwa dalam hal ini bahwa hasil penelitian tidak ada responden yang mengalami tidak ada kecemasan, kecemasan sedang dan kecemasan berat. Hasil temuan pada penelitian menunjukkan bahwa responden yang mengalami kecemasan ringan yaitu 22 responden $(100 \%)$.

Tingkat kecemasan menurut HARS (Hamilton Anxiety Rating Scale), dilihat dari 14 gejala kecemasan yang digolongkan secara fisiologis dan psikologis, gejala kecemasan fisiologis meliputi ketakutan, gejala somatik, gejala sensorik, gejala kardiovaskuler, gejala gastrointestinal, gejala urogenital, gangguan vegetatif / otonom. Sedangkan secara psikologis meliputi perasaan cemas, ketegangan, gangguan tidur, gangguan kecerdasan, perasaan depresi, gangguan pernafasan dan apa yang dirasakan oleh responden yang mengalami perubahan fisiologi selama kehamilan.

Kecemasan ringan berhubungan dengan ketegangan dalam kehidupan sehari-hari dan menyebabkan seorang menjadi waspada dan meningkatkan lahan persepsinya (Suliswati, 2005:109).

Pada kecemasan ringan, mekanisme koping yang biasanya digunakan adalah menangis, tidur, makan, tertawa, berkhayal, memaki, merokok, olah raga, mengurangi kontak mata dengan orang lain, membatasi diri pada orang lain (Suliswati, 2005:116). 
Menurut Suliswati (2005:115) respon pada kecemasan ringan ada 4 respon. Yang pertama yaitu respon fisiologis, tanda-tandanya sesekali nafas pendek, nadi dan tekanan darah naik, gejala ringan pada lambung, muka berkerut dan bibir bergetar. Respon kedua yaitu respon kognitif yaitu lapang persepsi meluas mampu menerima rangsangan yang kompleks dan konsentrasi pada masalah dan menyelesaikan dengan baik. Respon yang ketiga yaitu respon psikologis yaitu menarik diri dan menurunkan keterlibatan dengan orang lain. Respon yang terakhir yaitu respon afektif klien akan mengekpresikan dalam bentuk kebingungan dan curiga sebagai reaksi emosi terhadap kecemasan seperti tidak dapat duduk tenang, tremor halus pada tangan, dan suara kadang-kadang meninggi.

Pada penelitian ini selur 30 responden $(100 \%)$ mengala kecemasan ringan. Responden yang mempengaruhi kecemasan ringan yang dialami oleh responden. Hal ini disebabkan karena paling banyak responden dengan umur 21-25 tahun, sehingga pada umur tersebut seseorang akan memiliki rasa cemas apabila kehamilannya terganggu akibat perubahan yang sedang dihadapinya meskipun kecemasan yang dialaminya hanyalah kecemasan ringan. Responden yang mempunyai pengetahuan tinggi akan mampu mengatasi perubahan fisiologi yang terjadi selama kehamilan tanpa adanya rasa cemas. Sedangkan responden yang mempunyai pengetahuan kurang maka mereka belum mampu mengatasi perubahan tersebut dan mereka pasti akan merasa cemas. mengalami kecemasan ringan dikarenakan ibu hamil banyak yang sudah mendapat dukungan dari orang terdekat misalnya suami, orang tua, teman dan sahabat, selain itu juga mendapatkan perawatan yang tepat dalam mengatasi perubahan fisiologis yang diberikan oleh tenaga kesehatan khususnya bidan yaitu mengatasi kecemasan dengan memberikan penerangan mengenai fisiologi kehamilan, persalinan dan nifas. Dukungan dari keluarga juga dapat menyelesaikan krisis yaitu dengan memberikan ketrampilan koping untuk menyelesaikan masalah dan mengatasi kecemasan dengan melakukan aktivitas seperti menceritakan kejadian yang dialami, melakukan oleh raga, mendengarkan musik, menangis. Dengan melakukan aktifitas tersebut, dapat membantu mengurangi kecemasan yang dialami ibu hamil. Selain itu, umur responden juga

Diharapkan dengan tingginya pengetahuan responden maka semakin rendah tingkat kecemasan, begitu juga sebaliknya semakin rendah pengetahuan maka akan semakin tinggi tingkat kecemasan.

\section{Simpulan}

Dalam penelitian ini terbukti bahwa primigravida dalam menghadapi perubahan fisiologi selama kehamilan semuanya merasa cemas. . Dari 22 responden yang dijadikan sampel pada penelitian tanggal 11 -23 Juli 2011 di BPS Ny. Anik Desa Jekek Kecamatan Baron Kabupaten Nganjuk dapat disimpulkan tingkat kecemasan primigravida dalam menghadapi 
Siti Komariyah; Hubungan Pengetahuan Multigravida TM III Tentang Tanda - tanda Bahaya Kehamilan

Dengan Pemeriksaan Kehamilan

perubahan fisiologi selama

kehamilan yaitu :

1. Tidak ada responden yang mengalami tidak ada kecemasan.

2. Responden yang mengalami kecemasan tingkat ringan sebanyak 22 responden $(100 \%)$.

Faktor yang mempengaruhi adalah umur responden yaitu 21 - 25 tahun sebanyak 11 responden $(50 \%)$.

3. Tidak ada responden yang mengalami kecemasan tingkat sedang.

\section{DAFTAR PUSTAKA}

Arikunto, Suharsimi. (2006). Prosedur Penelitian Suatu Pendekatan Praktik. Jakarta : Rineka Cipta.

Fakultas Kedokteran UNPAD. (2003). Obstetri Fisiologi. Bandung : Elemen.

Hidayat, Alimul Aziz. (2010). Metode Penelitian Kebidanan dan Teknik Analisis Data. Jakarta : Salemba Medika.

Manuaba, Ida Bagus Gde. (2002). Ilmu Kebidanan, Penyakit Kandungan dan

Keluarga Berencana Untuk Pendidikan Bidan. Jakarta : EGC.

Mandriwati, G.A. (2008). Penuntun Belajar Asuhan Kebidanan Ibu Hamil. Jakarta : EGC.

Notoatmodjo, Soekidjo. (2005). Metodologi

Penelitian Kesehatan. Jakarta : Rineka Cipta. (2003). Konsep dan Penerapan Metodologi Penelitian Ilmu

Keperawatan. Jakarta : Salemba Medika.

Sunaryo. (2004). Psikologi Untuk Keperawatan. Jakarta : EGC.

Suliswati. (2005). Konsep Dasar Keperawatan Kesehatan Jiwa. Jakarta : EGC

Nursalam. (2001). Metodologi Riset Keperawatan. Jakarta : Sagung Seto.
4. Tidak ada responden yang mengalami kecemasan tingkat berat.
Sulistyoningsih, Hariyani. (2011). Gizi Untuk Kesehatan Ibu dan Anak. Yogyakarta : Graha Ilmu.

Agus. (2008). Prosentase Rasa Cemas.

[http://repository.usu.ac.id/bitstream/1234567 89/24374/4/Chapter\%20I.pdf. Accessed Juni 2011]

Grahacendekia. (2011). Tingkat Pengetahuan Primigravida Tentang Perubahan

Fisik Yang Terjadi Selama Kehamilan. [http://grahacendikia.wordpress.com/ 2011/04/30/ tingkat pengetahuan primigravida tentang perubahan fisik yang terjadi selama kehamilan. Accessed juni 2011]

Iklanmarker. (2001). Tingkat Pengetahuan Ibu Primigravida. [http://www.iklanmarket.cz.cc/2011/0 4/ tingkat pengetahuan ibu primigravida.html. Accessed Juni 2011]

Repository. (2011). Gangguan Kecemasan. [http://repository.usu.ac.id/bitstream/ 123456789/24374/4/Chapter\%20I.pdf . Accessed Juni 2011

Susiaty. (2008). Penyebab Kecemasan. [http: //library. Gunadarma.ac.id. Accessed Juni 2011]

Susilawati. (2009). Perubahan Fisiologis dan Anatomis Kehamilan. [http://kmii-kansai.net/new/?p=112. Acceessed Juni 2011] 
